University of Nebraska - Lincoln DigitalCommons@University of Nebraska - Lincoln

USDA National Wildlife Research Center - Staff U.S. Department of Agriculture: Animal and Plant Publications Health Inspection Service

2012

Introduction: Double-crested Cormorants of the Great Lakes - St. Lawrence River Basin: Recent Studies, Movements and Responses to Management Actions

D.V. Chip Weseloh

Canadian Wildlife Service, chip.weseloh@ec.gc.ca

Francesca J. Cuthbert

University of Minnesota

D. Tommy King

USDA/APHIS/WS National Wildlife Research Center, tommy.king@aphis.usda.gov

Follow this and additional works at: https://digitalcommons.unl.edu/icwdm_usdanwrc

Part of the Life Sciences Commons

Weseloh, D.V. Chip; Cuthbert, Francesca J.; and King, D. Tommy, "Introduction: Double-crested Cormorants of the Great Lakes - St. Lawrence River Basin: Recent Studies, Movements and Responses to Management Actions" (2012). USDA National Wildlife Research Center - Staff Publications. 1596.

https://digitalcommons.unl.edu/icwdm_usdanwrc/1596

This Article is brought to you for free and open access by the U.S. Department of Agriculture: Animal and Plant Health Inspection Service at DigitalCommons@University of Nebraska - Lincoln. It has been accepted for inclusion in USDA National Wildlife Research Center - Staff Publications by an authorized administrator of DigitalCommons@University of Nebraska - Lincoln. 


\title{
Introduction: Double-crested Cormorants of the Great Lakes - St. Lawrence River Basin: Recent Studies, Movements and Responses to Management Actions
}

\author{
D. V. Chip Weseloh ${ }^{1, *}$, Francesca J. Cuthbert ${ }^{2}$ and D. Tommy King ${ }^{3}$ \\ ${ }^{1}$ Canadian Wildlife Service, Environment Canada, 4905 Dufferin Street, Toronto, ON, M3H 5T4, Canada
}

${ }^{2}$ Dept. Fisheries, Wildlife and Conservation Biology, 1980 Folwell Avenue, University of Minnesota, St. Paul, MN, 55108, USA

${ }^{3}$ U.S. Department of Agriculture, Wildlife Services, National Wildlife Research Center, P.O. Box 6099, Mississippi State University, MS, 39762, USA

* Corresponding author; E-mail: chip.weseloh@ec.gc.ca

\begin{abstract}
This paper introduces the second Special Publication of the Waterbird Society to address the biology and management of the Double-crested Cormorant (Phalacrocorax auritius) in North America. Since the late 1960s and early 1970s, when the species was at very low population levels, the Double-crested Cormorant has rebounded to its greatest population level in over 100 years. Such a significant increase has resulted in changes in community structure, and new stressors, in many aquatic ecosystems. Both Special Publications (1995 and 2013 ) have been focused on the biology and management of the species. The first volume dealt mainly with population growth and the resulting, immediate management issues. In the current volume, studies address the longer term situation, the implementation of two U.S. depredation orders and new research directions identified in the first Special Publication and in subsequent smaller cormorant symposia. Seventeen papers which comprise this volume are presented under six headings: introduction, impacts to natural resources, population dynamics, evaluation of control efforts, assessing fish consumption and bioenergetics, migration ecology and local and seasonal movements, and summary overview and future information needs. A second Special Publication on Double-crested Cormorants gives us an opportunity to assess how well cormorant biologists have addressed and answered questions we posed to ourselves 15 years earlier; it also provides us with a vision for the next 18 years. Received 10 October 2011, accepted 1 April 2012.
\end{abstract}

Key words.-Double-crested Cormorant, Great Lakes, Symposium.

Waterbirds 35(Special Publication 1): 1-3, 2012

In North America, the Double-crested Cormorant (Phalacrocorax auritus; henceforth cormorant) population was affected greatly by eggshell thinning caused by organochlorine contamination beginning as early as 1955 (Anderson and Hickey 1972). In 1972, it was "Blue-listed" by the National Audubon Society as a species in potential trouble (Tate and Tate 1982). The two most severely impacted meta-populations were in southern California (Gress et al. 1973) and the Great Lakes. The Great Lakes meta-population declined from $900^{+}$nesting pairs distributed over all five lakes in the 1950 s to fewer than 100 breeding pairs in four Lakes by 1970 (Postupalsky 1978; Weseloh et al. 1983). With the banning or restrictive use of both DDT and PCBs in the early 1970s, the species began to recover, especially on the Great Lakes (Scharf and Shugart 1981; Weseloh et al. 1983). By the mid-1980s, it was clear that cormorant numbers had re- covered and expanded to a greater extent than any biologist had likely observed in his or her lifetime. On the Great Lakes, cormorant numbers surpassed the pre-DDT era population levels (900 nests) by 1981 (Weseloh et al. 1995). By 2005, there were more than 100,000 cormorant nests on the Great Lakes (Great Lakes Double-crested Cormorant Management Working Group unpubl. data).

The dramatic increase in cormorant numbers and subsequent expansion of colony locations and wintering grounds (Glahn and Stickley 1995) led to concerns about cormorant impacts to other natural resources. The major concerns were impacts to native and farmed fishery resources, and impacts to vegetation and competition with co-nesting species on breeding colonies. For some of these concerns, there was fairly clear-cut evidence, e.g. cormorants do kill vegetation on their breeding colonies (Lemmon et al. 1994; He- 
bert et al. 2005). In many cases, cormorants were suspected of impacting co-nesting species, especially Black-crowned Night-Herons (Nycticorax nycticorax) (Cuthbert et al. 2002; Weseloh et al. 2002). With respect to possible impacts to fisheries, the extent of this relationship was quite controversial. To many fisheries interests (managers, researchers and sporting groups), a cause-and-effect relationship was clear cut: if 1,000 cormorants (500 nesting pairs) ate a pound of fish per day from mid-April through mid-September (154 days), they would consume about 154,000 pounds (ca. $77 \mathrm{t}$ ) of fish; there had to be an effect! To avian researchers and managers, a cause-and-effect relationship, based on sound science, had to be demonstrated to support any management actions that might be taken. While this discussion/ debate was going on, cormorant numbers continued to increase. On the Great Lakes, the number of cormorant nests (= breeding pairs) increased from 5,400 in 1986 to 25,000 by 1991 (Weseloh et al. 1995). With the increasing call for cormorant management actions, it also became clear that except for very few studies, little was known about basic cormorant biology. Information was especially lacking regarding population dynamics, age-specific mortality, impacts to fisheries and co-nesting colonial waterbirds, local movements, management practices, etc. Thus, in 1992, biologists gathered to assess the situation of cormorants across North America (Nettleship and Duffy 1995).

Certainly, one of the major changes in addressing potential cormorant conflict issues since the first Waterbird Society-published symposium (Nettleship and Duffy 1995) has been the enactment of two U.S. Fish and Wildlife Service depredation orders: an Aquatic Depredation Order in 1998 and a Natural Resources Depredation Order in 2003 (50 CFR 21.47 and 50 CFR 21.48, respectively, http://www.fws.gov/migratorybirds / CurrentBirdIssues/Management/ cormorant/cormorant.html). These policy initiatives have resulted in a regional-scale (state by state) management approach to managing cormorant populations in designated states. Likewise in Canada, manage- ment was addressed on a province-by-province basis. In both countries, it was the public outcry about cormorant-fisheries conflicts and cormorant-habitat conflicts that led to various management actions. Such public pressure also brought greatly increased research dollars to investigate aspects of the biology of the cormorant that appeared to compromise other natural resources, factors which had been unstudied previously. Funding also made large-scale research possible (e.g. long-term colony dynamics and movement studies). Now, almost 20 years later, and following several other local/regional cormorant conferences (e.g. Tobin 1999; Stapanian 2002), biologists and managers again came together in 2007. At this meeting, we assessed the status of research and management of cormorants, primarily on the Great Lakes, a region that now hosts over 100,000 pairs of nesting cormorants and a late summer population estimated at half a million individuals (Great Lakes Double-crested Cormorant Management Working Group unpubl. data). The purpose of this Introduction to these proceedings is to set the stage for a recent compilation of research, monitoring and management actions for this high-profile species.

The conference was held from 28 May to 1 June 2007 at Pennsylvania State University, State College, PA, as part of the $54^{\text {th }}$ annual meeting of the International Association of Great Lakes Research. This publication is a compilation of papers dealing with both freshwater and marine aspects of the life history of cormorants that were delivered at the symposium, as well as select few others addressing the theme of the Symposium, i.e. Double-crested Cormorants of the Great Lake -St. Lawrence River Basin: recent studies, movements and responses to management actions on their biology/ecology.

\section{Acknowledgments}

We are indebted to the International Association for Great Lakes Research (IAGLR) for including the Symposium on Double-crested Cormorants, from which most of the papers contained herein were taken, as part of their 54th annual meeting. We also wish to express our great appreciation to both the U.S. Fish and Wild- 
life Service (U.S. Department of the Interior) and the National Wildlife Research Center, (Wildlife Services, U.S. Department of Agriculture) for partially funding the preparation of this volume. Of course, the volume would not have been possible without the many authors who contributed their research findings and time in presenting and preparing their work We are also grateful to the many individuals who were part of the peerreview process: B. Blackwell, H. Blokpoel, G. Cabana, D. Capen, J. Coleman, T. Custer, F. Cuthbert, E. Davies, S. DeSolla, B. Dorr, A. Duerr, S. Elbin, J. Ellis, G. Fox, J. Farquhar, S. Gabrey, C. Hebert, K. Hobson, T. King, S. Lewis, D. Moore, R. Morris, C. Mulder, K. Parsons, S. Petrie, J. Quinn, M. Ridgway, G. Russell, M. Seamans, N. Seefelt, K. Stromborg, L. Shutt, C. Somers, B. Strickland, C. Weseloh and L. Wires (apologies to anyone we missed!). We are also most appreciative to Barry Kent MacKay for the cover illustration. Lastly, we wish to acknowledge V. Kjoss for copy-editing and E. Campbell for final editorial assistance. R. Elner, our Editor-inChief, provided editorial guidance and encouragement throughout the long process of bringing these papers and this volume to fruition; for that we are most appreciative.

\section{Literature Cited}

Anderson, D. W. and J. J. Hickey. 1972. Eggshell changes in certain North American birds. Proceedings of the International Ornithological Congress 15: 514-540.

Cuthbert, F. J., L. R. Wires and J. E. McKearnan. 2002. Potential impacts of nesting double-crested cormorants on great blue herons and black-crowned nightherons in the U.S. Great Lakes. Journal of Great Lakes Research 28: 145-154.

Glahn, J. F. and A. R. Stickley, Jr. 1995. Wintering Double-crested Cormorants in the Delta Region of Mississippi: Population levels and their impact on the catfish industry. Colonial Waterbirds 18 (Special Publication 1): 137-142.

Gress, F., R. W. Riseborough, D. W. Anderson, L. F. Kiff and J. R. Jehl, Jr. 1973. Reproductive failures of Double-crested Cormorants in southern California and Baja California. Wilson Bulletin 85: 197-208.
Hebert, C. E., J. Duffe, D. V. C. Weseloh, E. M. T. Senese and G. D. Haffner. 2005. Unique island habitats may be threatened by Double-crested Cormorants. Journal of Wildlife Management 69: 57-65.

Lemmon, C. R., G. Bugbee and G. R. Stephen. 1994. Tree damage by nesting Double-crested Cormorants in Connecticut. Connecticut Warbler 14: 27-30.

Nettleship, D. N. and D. C. Duffy, Eds. 1995. The Double-crested Cormorant: Biology, Conservation and Management. Colonial Waterbirds 18 (Special Publication 1).

Postupalsky, S. 1978. Toxic chemicals and cormorant populations in the Great Lakes. Canadian Wildlife Service, Wildlife Toxicology Division Manuscript Report No. 40. Ottawa, Ontario.

Scharf, W. C. and G. W. Shugart. 1981. Recent increases in Double-crested Cormorants in the United States Great Lakes. American Birds 35: 910-911.

Stapanian, M. A. 2002. Interspecific interactions, habitat use, and management of Double-crested Cormorants (Phalacrocorax auritus) in the Laurentian Great Lakes: An Introduction. Journal of Great Lakes Research 28: 119-124.

Tate, J. and D. J. Tate. 1982. The Blue List and the list of species of Special Concern. American Birds 36: 129-134.

Tobin, M. E., Tech. Coord. 1999. Symposium on Double-crested Cormorants: Population Status and Management Issues in the Midwest. Technical Bulletin No. 1879. United States Department of Agriculture, Animal and Plant Health Inspection Service, Washington, D.C.

Weseloh, D. V., P. J. Ewins, C. A. Bishop, J. Struger, P. Mineau, S. Postuplasky and J. P. Ludwig. 1995. Double-crested Cormorants of the Great Lakes: changes in population size, breeding distribution and reproductive output between 1913 and 1991. Colonial Waterbirds 18 (Special Publication 1): 48-59.

Weseloh, D. V., C. Pekarik, T. Havelka, G. Barrett and J. Reid. 2002. Population trends and colony locations of Double-crested Cormorants in the Canadian Great Lakes and immediately adjacent areas, 1990-2000: A manager's guide. Journal of Great Lakes Research 28: 125-144. 